\title{
Novel $\mathbf{N}$-Benzenesulfonyl Sophocarpinol Derivatives as Coxsackie B Virus Inhibitors
}

Sheng Tang, ${ }^{\dagger, \S}$ Lanying Kong, ${ }^{\dagger} \S$ Yinghong Li, ${ }^{\dagger}$ Jiandong Jiang, ${ }^{\dagger \neq}$ Limei Gao, ${ }^{\dagger}$ Xinyue Cheng, ${ }^{\dagger}$ Linlin Ma, $^{\dagger}$ Xin Zhang, ${ }^{\dagger}$ Yuhuan $\mathrm{Li}^{*}{ }^{* \dagger}$ and Danqing Song ${ }^{*},^{\dagger}$

${ }^{\dagger}$ Institute of Medicinal Biotechnology, Chinese Academy of Medical Science \& Peking Union Medical College, Beijing 100050, China

${ }^{\ddagger}$ State Key Laboratory of Bioactive Substance and Functions of Natural Medicines, Institute of Materia Medica, Chinese Academy of Medical Sciences and Peking Union Medical College, Beijing 100050, China

\section{Supporting Information}

ABSTRACT: Novel $N$-benzenesulfonyl sophocarpinic acid/ ester and sophocarpinol derivatives were synthesized and evaluated for their antienteroviral activities against coxsackievirus type B3 (CVB3) from sophocarpine (1), a natural medicine isolated from Chinese herb. Structure-activity relationship (SAR) analysis revealed that the double bond and its geometrical configuration and position at the C-11 attachment did not greatly affect the potency. Among these
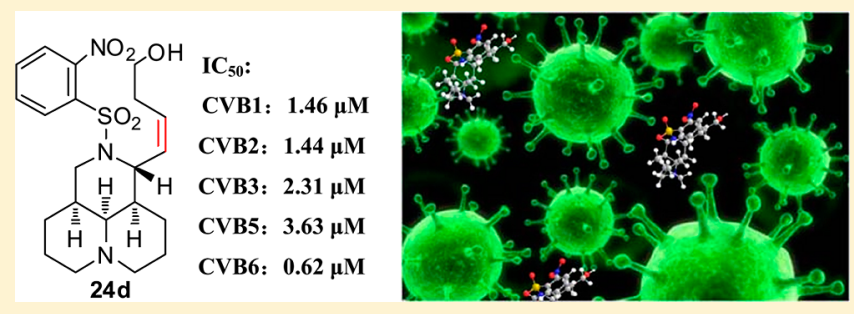
derivatives, sophocarpinol 24d exerted the promising activities against not only CVB3 but also CVB1, CVB2, CVB5, and CVB6 with $\mathrm{IC}_{50}$ ranging from 0.62 to $3.63 \mu \mathrm{M}$ (SI from 46 to 275 ), indicating a broad-spectrum antienteroviral characteristic. The SAR results provided the powerful information for further strategic optimization and development of a novel scaffold of broad-spectrum antiviral candidates against enteroviruses.

KEYWORDS: Sophocarpine, sophocarpinol, structure-activity relationship, enteroviruse, coxsakievirus type B3

$\mathrm{E}$ nteroviruses are a genus of single-stranded (+) RNA viruses associated with many human diseases. ${ }^{1,2}$ Among

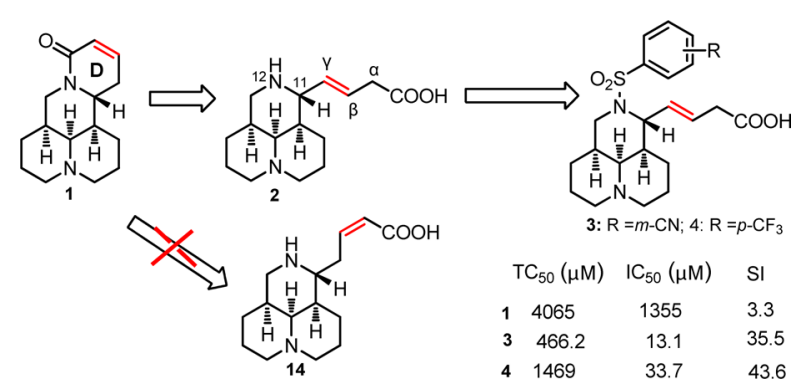

Figure 1. Chemical structures of sophocarpine $(1) ; E-\beta, \gamma$-sophocarpinic acid (2); $E-\beta, \gamma-12-\mathrm{N}-m$-cyanobenzene-sulfonyl sophocarpinic acid (3); $E-\beta, \gamma-12-N$-p-trifluoromethy-benzenesulfonyl sophocarpinic acid (4); and $Z$ - $\alpha, \beta$-sophocarpinic acid (14).

the enteroviruses, coxsackie $\mathrm{B}$ viruses $(\mathrm{CVB})$ are important human pathogens causing pleurodynia, myocarditis, hepatitis, and so on. ${ }^{3,4}$ Coxsackievirus type B3 (CVB3) is an important pathogen that induces acute and chronic viral myocarditis in children and young adults, and eventually leads to cardiomyopathy. ${ }^{5,6}$ Besides heart infections, CVB3 causes chronic inflammatory diseases of the pancreas and central nervous system as well. ${ }^{7,8}$ In recent years, the sudden epidemic infections of enteroviruses have caused great concerns of society. ${ }^{9-11}$ However, there has been no special efficient drug approved for the treatment of the infections caused by CVB3
Scheme $1^{a}$

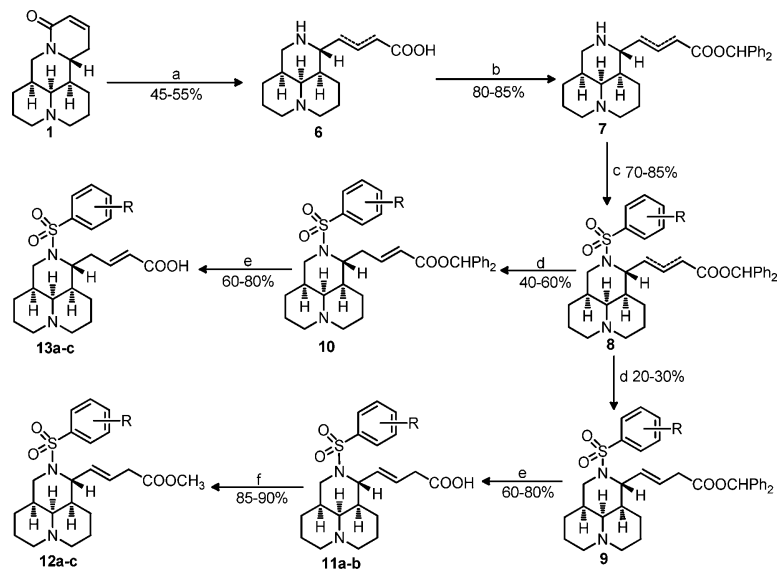

${ }^{a}$ Reagents and conditions: (a) $5 \mathrm{~N} \mathrm{NaOH}$, reflux, 9 h, $2 \mathrm{~N} \mathrm{HCl}, \mathrm{pH}=$ 5-6; (b) diphenyldiazomethane, $\mathrm{MeOH}$, r.t., $12 \mathrm{~h}$; (c) $\mathrm{RPhSO}_{2} \mathrm{Cl}$, $\mathrm{K}_{2} \mathrm{CO}_{3}, \mathrm{CH}_{2} \mathrm{Cl}_{2}$, r.t., overnight; (d) flash column chromatography; (e) m-cresol, reflux, 8-9 h; (f) $2 \mathrm{~N} \mathrm{HCl} / \mathrm{MeOH}$, reflux, $2 \mathrm{~h}$.

until now. ${ }^{12}$ Therefore, there is an urgent need to develop broad-spectrum antiviral candidates against enteroviruses to meet an emergency of sudden infectious diseases.

Received: October 23, 2014

Accepted: January 7, 2015

Published: January 7, 2015 
Scheme $2^{a}$

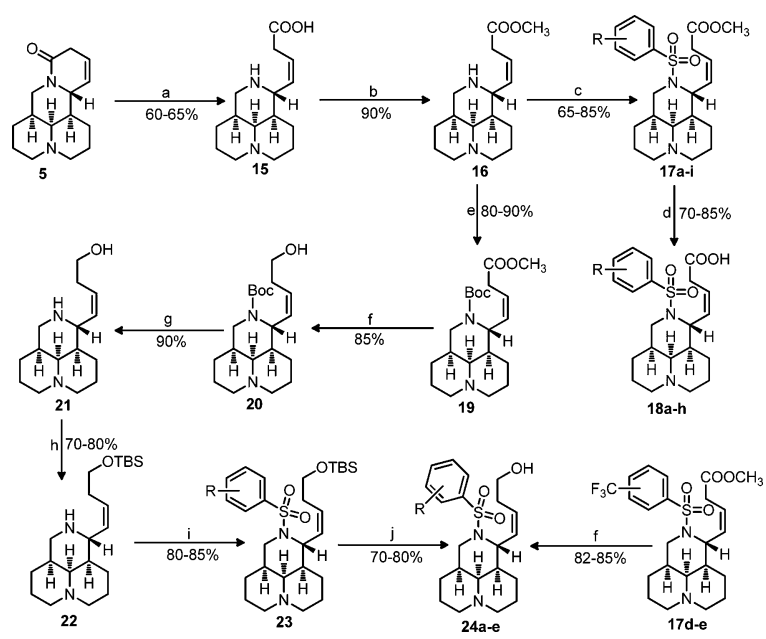

${ }^{a}$ Reagents and conditions: (a) $5 \mathrm{~N} \mathrm{HCl}$, reflux, 9 h; (b) $2 \mathrm{~N} \mathrm{HCl} /$ $\mathrm{MeOH}$, reflux, $2 \mathrm{~h}$; (c) $\mathrm{RPhSO}_{2} \mathrm{Cl}, \mathrm{K}_{2} \mathrm{CO}_{3}, \mathrm{CH}_{2} \mathrm{Cl}_{2}$, r.t., overnight; (d) $3 \mathrm{~N} \mathrm{HCl}$, reflux, $3 \mathrm{~h}$; (e) $\mathrm{Boc}_{2} \mathrm{O}, \mathrm{K}_{2} \mathrm{CO}_{3}, \mathrm{CH}_{2} \mathrm{Cl}_{2}$, r.t., overnight; (f) $\mathrm{LiAlH}_{4}$, THF, r.t., $30 \mathrm{~min}$; (g) $2 \mathrm{~N} \mathrm{HCl} / \mathrm{Et}_{2} \mathrm{O}, 30 \mathrm{~min}$; (h) TBSCl, $\mathrm{CH}_{2} \mathrm{Cl}_{2}$, imidazole, r.t., overnight; (i) $\mathrm{RPhSO}_{2} \mathrm{Cl}$, TEA, $\mathrm{CH}_{2} \mathrm{Cl}_{2}$, r.t., 4 h; (j) $2 \mathrm{~N} \mathrm{HCl}$.

Scheme $3^{a}$

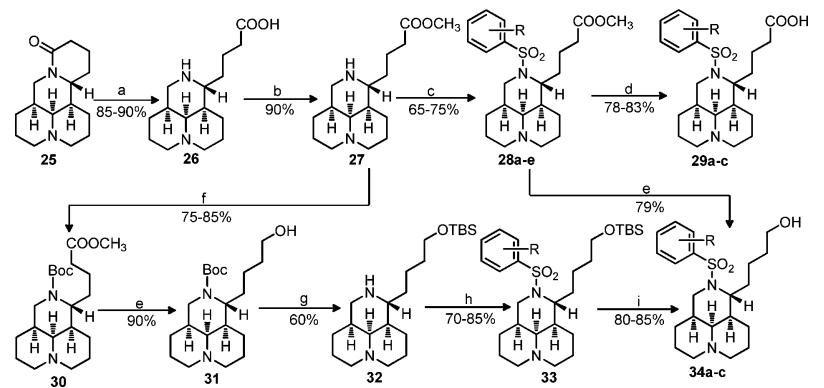

${ }^{a}$ Reagents and conditions: (a) $5 \mathrm{~N} \mathrm{NaOH}$, reflux, $9 \mathrm{~h}, 2 \mathrm{~N} \mathrm{HCl}, \mathrm{pH}=$ 5-6; (b) $2 \mathrm{~N} \mathrm{MeOH} / \mathrm{HCl}$, reflux, $2 \mathrm{~h}$; (c) $\mathrm{RPhSO}_{2} \mathrm{Cl}_{2} \mathrm{~K}_{2} \mathrm{CO}_{3}$, $\mathrm{CH}_{2} \mathrm{Cl}_{2}$, r.t., overnight; (d) $3 \mathrm{~N} \mathrm{HCl}$, reflux, $3 \mathrm{~h}$; (e) $\mathrm{LiAlH}_{4}$, THF, r.t., 30 min; (f) $\mathrm{Boc}_{2} \mathrm{O}, \mathrm{CH}_{2} \mathrm{Cl}_{2}, \mathrm{~K}_{2} \mathrm{CO}_{3}$, r.t., overnight; (g) TBSCl, $\mathrm{CH}_{2} \mathrm{Cl}_{2}$, imidazole, r.t., overnight; (h) $\mathrm{RPhSO}_{2} \mathrm{Cl}$, TEA, 4-DMAP, $\mathrm{CH}_{2} \mathrm{Cl}_{2}$, r.t., 4 h; (i) $2 \mathrm{~N} \mathrm{HCl}$, r.t., 2 h.

Sophocarpine (1, Figure 1), a natural medicine extracted from Chinese herb Sophora flavescens, has been used to treat viral myocarditis caused by CVB3 for decades in China with an unknown mechanism of action. ${ }^{13,14}$ The primary structureactivity relationship (SAR) investigation had been carried out with D-ring opening from compound 1, and SAR results indicated that $E$ - $\beta, \gamma$-sophocarpinic acid (2, Figure 1) with a 3ring core was more favorable than 1 with a 4-ring scaffold. As described in Figure 1, the representative $N$-benzenesulfonyl sophocarpinic acids $\mathbf{3}$ and $\mathbf{4}$ were identified with higher potency than lead $1,{ }^{15}$ and an effort to further improve the potency via modification and optimization was carried out, in order to develop a novel family of antienteroviral candidates against CVB3. In the present study, using $\mathbf{3 / 4}$ as the leads, the SAR study was mainly focused on the variations of the carboxyl group and carbon-carbon double bond located at the C-11 attachment, while 12-benzenesulfonyl moiety on the $\mathrm{N}-12$ atom was maintained as a required group for CVB3. ${ }^{15}$ Herein, we reported the synthesis, SAR analysis, and in vitro anti-CVB3
Table 1. Structure-Activity Relationship of Newly Synthesized Compounds against CVB3

\begin{tabular}{|c|c|c|c|c|c|}
\hline compd & $\mathrm{R}_{1}$ & $\mathrm{R}_{2}$ & $\mathrm{TC}_{50}(\mu \mathrm{M})^{a}$ & $\mathrm{IC}_{50}(\mu \mathrm{M})^{b}$ & $\mathrm{SI}^{c}$ \\
\hline 3 & $m-\mathrm{CN}$ & $\mathrm{COOH}$ & 466.2 & 13.1 & 35.5 \\
\hline 4 & $p-\mathrm{CF}_{3}$ & $\mathrm{COOH}$ & 1469 & 33.7 & 43.6 \\
\hline $11 \mathrm{a}$ & $o-\mathrm{CN}$ & $\mathrm{COOH}$ & 466.2 & 22.7 & 20.5 \\
\hline $11 b$ & $o-\mathrm{CF}_{3}$ & $\mathrm{COOH}$ & 393.3 & 11.1 & 15.6 \\
\hline $12 a$ & $m-\mathrm{CN}$ & $\mathrm{CO}_{2} \mathrm{CH}_{3}$ & 72.4 & 7.30 & 9.9 \\
\hline $12 b$ & $o-\mathrm{CN}$ & $\mathrm{CO}_{2} \mathrm{CH}_{3}$ & 80.3 & 8.92 & 9.0 \\
\hline $12 \mathrm{c}$ & $o-\mathrm{CF}_{3}$ & $\mathrm{CO}_{2} \mathrm{CH}_{3}$ & 38.1 & 11.9 & 3.2 \\
\hline $13 a$ & $o-\mathrm{CN}$ & $\mathrm{COOH}$ & 466.2 & $>155.4$ & \\
\hline $13 b$ & $p-\mathrm{CN}$ & $\mathrm{COOH}$ & $>466.2$ & 29.9 & $>15.7$ \\
\hline $13 \mathrm{c}$ & $o-\mathrm{CF}_{3}$ & $\mathrm{COOH}$ & 423.7 & 27.2 & 35.5 \\
\hline $17 a$ & $o-\mathrm{CN}$ & $\mathrm{CO}_{2} \mathrm{CH}_{3}$ & 289.2 & 4.21 & 68.7 \\
\hline $17 b$ & $m-\mathrm{CN}$ & $\mathrm{CO}_{2} \mathrm{CH}_{3}$ & 542.6 & 3.07 & 176.7 \\
\hline $17 \mathrm{c}$ & $p-\mathrm{CN}$ & $\mathrm{CO}_{2} \mathrm{CH}_{3}$ & 292.0 & 8.04 & 36.3 \\
\hline $17 d$ & $m-\mathrm{CF}_{3}$ & $\mathrm{CO}_{2} \mathrm{CH}_{3}$ & 198.0 & 2.24 & 88.3 \\
\hline $17 \mathrm{e}$ & $p-\mathrm{CF}_{3}$ & $\mathrm{CO}_{2} \mathrm{CH}_{3}$ & 54.7 & 8.17 & 6.7 \\
\hline $17 \mathrm{f}$ & $o-\mathrm{NO}_{2}$ & $\mathrm{CO}_{2} \mathrm{CH}_{3}$ & 481.2 & 5.23 & 92.1 \\
\hline $17 \mathrm{~g}$ & $m-\mathrm{NO}_{2}$ & $\mathrm{CO}_{2} \mathrm{CH}_{3}$ & 111.8 & 9.24 & 12.1 \\
\hline $17 \mathrm{~h}$ & $p-\mathrm{NO}_{2}$ & $\mathrm{CO}_{2} \mathrm{CH}_{3}$ & 185.5 & 7.02 & 26.4 \\
\hline $17 \mathrm{i}$ & & $\mathrm{CO}_{2} \mathrm{CH}_{3}$ & 21.1 & 1.19 & 17.7 \\
\hline $18 \mathrm{a}$ & $o-\mathrm{CN}$ & $\mathrm{COOH}$ & 429.6 & 27.6 & 15.6 \\
\hline $18 b$ & $m-\mathrm{CN}$ & $\mathrm{COOH}$ & 744.8 & 17.4 & 42.7 \\
\hline $18 \mathrm{c}$ & $p-\mathrm{CN}$ & $\mathrm{COOH}$ & 744.8 & 52.4 & 14.2 \\
\hline $18 \mathrm{~d}$ & $p-\mathrm{CF}_{3}$ & $\mathrm{COOH}$ & 272.4 & 18.6 & 14.7 \\
\hline $18 \mathrm{e}$ & $o-\mathrm{NO}_{2}$ & $\mathrm{COOH}$ & 594.6 & 16.2 & 36.8 \\
\hline $18 \mathrm{f}$ & $m-\mathrm{NO}_{2}$ & $\mathrm{COOH}$ & 445.4 & 63.6 & 7.0 \\
\hline $18 \mathrm{~g}$ & $p-\mathrm{NO}_{2}$ & $\mathrm{COOH}$ & 308.8 & 49.8 & 6.2 \\
\hline $18 \mathrm{~h}$ & & $\mathrm{COOH}$ & 191.2 & 53.1 & 3.6 \\
\hline $24 a$ & $m-\mathrm{CN}$ & $\mathrm{CH}_{2} \mathrm{OH}$ & 147.7 & 5.47 & 27.0 \\
\hline $24 b$ & $m-\mathrm{CF}_{3}$ & $\mathrm{CH}_{2} \mathrm{OH}$ & 93.5 & 15.0 & 6.2 \\
\hline $24 c$ & $p-\mathrm{CF}_{3}$ & $\mathrm{CH}_{2} \mathrm{OH}$ & 93.5 & 4.17 & 22.4 \\
\hline $24 d$ & $o-\mathrm{NO}_{2}$ & $\mathrm{CH}_{2} \mathrm{OH}$ & 353.5 & 2.31 & 152.9 \\
\hline $24 \mathrm{e}$ & $p-\mathrm{NO}_{2}$ & $\mathrm{CH}_{2} \mathrm{OH}$ & 265.4 & 17.03 & 15.6 \\
\hline RBV & & & 8197 & 694.6 & 11.8 \\
\hline
\end{tabular}

${ }^{a}$ Cytotoxic concentration required to inhibit Vero cell growth by $50 \%$. ${ }^{b}$ Concentration required to inhibit CVB3 growth by $50 \%$. ${ }^{c}$ Selectivity index: $\mathrm{TC}_{50} / \mathrm{IC}_{50}$.

evaluation of a series of novel $\mathrm{N}$-benzenesulfonyl sophocarpinic acid/ester and sophocarpinol derivatives.

Forty-one target compounds were prepared with commercially available $\mathbf{1}$, lehmannine (5), or matrine (25) as the starting material as described in Schemes 1-3, respectively. The D-ring in compound $\mathbf{1}$ was opened in alkaline conditions to produce an isomer mixture of $E$-sophocarpinic acid (6), and diphenyldiazomethane was then chosen as the protective agent to facilitate the separation of mixture 8 into its two isomers 9 and 10 with good yields. The desired acid products in 11 and $\mathbf{1 3}$ series were acquired by deprotection of $\mathbf{9}$ or $\mathbf{1 0}$ in $m$-cresol with overall yields of $5-12 \%$ as reported previously. ${ }^{15,16}$ The sophocarpinic esters $12 \mathrm{a}-\mathrm{c}$ were obtained via methyl esterification of $\mathbf{1 1}$ at refluxing temperature in $2 \mathrm{~N} \mathrm{HCl}$ / $\mathrm{CH}_{3} \mathrm{OH}$ in $85-90 \%$ yields.

As shown in Scheme 2, methanol was used as the protective agent in compound $\mathbf{1 6}$ so as to conveniently obtain the target 
Table 2. Structure-Activity Relationship for CVB3 of Some Aimed Compounds

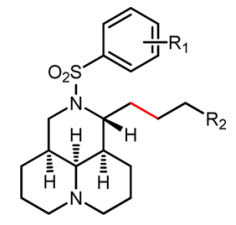

\begin{tabular}{cllccc} 
compd & \multicolumn{1}{c}{$\mathrm{R}_{1}$} & \multicolumn{1}{c}{$\mathrm{R}_{2}$} & $\mathrm{TC}_{50}(\mu \mathrm{M})^{a}$ & $\mathrm{IC}_{50}(\mu \mathrm{M})^{b}$ & $\mathrm{SI}^{c}$ \\
\hline 28a & $m-\mathrm{CN}$ & $\mathrm{CO}_{2} \mathrm{CH}_{3}$ & 288.0 & 11.7 & 24.6 \\
28b & $p-\mathrm{CF}_{3}$ & $\mathrm{CO}_{2} \mathrm{CH}_{3}$ & 73.4 & 2.54 & 28.9 \\
28c & $o-\mathrm{NO}_{2}$ & $\mathrm{CO}_{2} \mathrm{CH}_{3}$ & 398.8 & 23.9 & 16.7 \\
28d & $m-\mathrm{NO}_{2}$ & $\mathrm{CO}_{2} \mathrm{CH}_{3}$ & 68.9 & 3.51 & 19.7 \\
28e & $m-\mathrm{CF}_{3}$ & $\mathrm{CO}_{2} \mathrm{CH}_{3}$ & 193.3 & 1.98 & 92.4 \\
29a & $m-\mathrm{CN}_{2}$ & $\mathrm{COOH}$ & 427.8 & 82.3 & 5.2 \\
29b & $p-\mathrm{CF}_{3}$ & $\mathrm{COOH}$ & 391.7 & 75.4 & 5.2 \\
29c & $o-\mathrm{NO}_{2}$ & $\mathrm{COOH}$ & 410.3 & 78.9 & 5.2 \\
34a & $m-\mathrm{CN}^{2}$ & $\mathrm{CH}_{2} \mathrm{OH}$ & 147.0 & 11.3 & 13.0 \\
34b & $p-\mathrm{CF}_{3}$ & $\mathrm{CH}_{2} \mathrm{OH}$ & 232.6 & 6.55 & 35.5 \\
34c & $o-\mathrm{NO}_{2}$ & $\mathrm{CH}_{2} \mathrm{OH}$ & 243.9 & 35.7 & 6.8 \\
RBV & & & 8197 & 694.6 & 11.8
\end{tabular}

${ }^{a}$ Cytotoxic concentration required to inhibit Vero cell growth by $50 \%$. ${ }^{b}$ Concentration required to inhibit CVB3 growth by $50 \%$. ${ }^{c}$ Selectivity index: $\mathrm{TC}_{50} / \mathrm{IC}_{50}$.

products 17 with high yields as previously reported. ${ }^{17}$ Sophocarpinols $24 \mathbf{b}-\mathrm{c}$ bearing a $\mathrm{CF}_{3}$ substitution were directly gained through selective reduction of $\mathbf{1 7} \mathbf{d}-\mathbf{e}$ using $\mathrm{LiAlH}_{4}$ as the reducing agent in THF in $82-85 \%$ yields. ${ }^{17}$ In another synthetic route, the key intermediate 21 was acquired via $N$ tert-butoxycarbonyl (Boc) protection, ester reduction with $\mathrm{LiAlH}_{4}$, and Boc removal in $2 \mathrm{~N} \mathrm{HCl}$ from 16 with good yields. The sophocarpinols $24 \mathrm{a}$ and $\mathbf{2 4 d}-\mathbf{e}$ possessing $\mathrm{CN}$ or $\mathrm{NO}_{2}$ substitution were successfully achieved through hydroxyl protection of 21 with tert-butyldimethylsilyl (TBS), 12- Nbenzenesulfonyl substitution, and deprotection of 23 in $2 \mathrm{~N}$ $\mathrm{HCl}$ with overall yields of $26-32 \%$. Similarly, as depicted in Scheme 3, matrinic acids/esters (28a-e and $29 a-c)$ were semisynthesized from matrine with good yields as reported previously. ${ }^{16,17}$ As mentioned above, matrinol 34b possessing $\mathrm{CF}_{3}$ substitution was directly acquired from $28 \mathbf{b}$; while compounds $34 \mathrm{a}$ and $34 \mathrm{c}$ with $\mathrm{CN}$ or $\mathrm{NO}_{2}$ were obtained via a six-step sequence from compound 27 in high yields.

All the new target compounds were measured for their in vitro anti-CVB3 activities in African green monkey kidney (Vero) cells using viral cytopathogenic effect (CPE) assay with ribavirin (RBV) as the positive control. ${ }^{18}$ The potency against CVB3 of each tested compound was evaluated by the combination of its $\mathrm{IC}_{50}$ and selectivity index (SI) value as the important therapeutic indication.
The influence of the carboxyl group at the C-11 attachment was first explored. As shown in Table $1, E-\beta, \gamma$-sophocarpinic esters $(12 \mathbf{a}-\mathbf{c})$ exerted potent anti-CVB3 activities with $\mathrm{IC}_{50}$ between 7.3 and $11.9 \mu \mathrm{M}$ and high cytotoxic activities $\left(\mathrm{TC}_{50}=\right.$ $38-80 \mu \mathrm{M})$ to give SI values 3.2-9.9. Their corresponding sophocarpinic acid ( 3 and $\mathbf{1 1} \mathbf{a}-\mathbf{b})$ with weaker activities and toxicities gave SI values ranging from 15.6 to 35.5 . Then, $E-\alpha, \beta$ sophocarpinic acids $(13 \mathrm{a}-\mathrm{c})$ were generated to investigate whether the position of double bond would affect the activity. Compounds $13 b-c$ afforded activities comparable to their geometric isomers; while compound 13a lost its activity, suggesting the double bond located in $\beta, \gamma$-position is a little more beneficial than that in $\alpha, \beta$-position.

Next, SAR was moved on the impact of $Z$-configuration of double bond on the anti-CVB3 effect. Among Z-sophacarpinic ester analogues $(\mathbf{1 7} \mathbf{a}-\mathbf{i})$, all of them displayed excellent activities with $\mathrm{IC}_{50}$ between 1.19 and $9.24 \mu \mathrm{M}$, much better than that of their corresponding sophacarpinic acids $18 \mathbf{a}-\mathbf{h}$. Especially, compound $\mathbf{1 7 b}$ had a promising potency with an $\mathrm{IC}_{50}$ of $3.07 \mu \mathrm{M}$ and SI value of 176. Sophocarpinols $24 \mathrm{a}-\mathbf{e}$ showed good potency with $\mathrm{IC}_{50}$ below $17.0 \mu \mathrm{M}$, particularly, compound 24d exhibited an excellent potency with an $\mathrm{IC}_{50}$ of 2.31 ( $\mathrm{SI}=153)$, suggesting that the $o-\mathrm{NO}_{2}$ substituent might be helpful for the improved activity. The SAR results indicated that $E$ - or $Z$-configuration of the double-bond was not an important factor for potency. Then, the double-bond was removed, and a couple of matrinic acids/esters (28a-e and $29 a-c)$ and matrinols $(34 a-c)$ were constructed. As shown in Table 2, all of them displayed a favorable activity against CVB3 with SI ranging from 5.2 to 92, indicating that the double bond might not play the key role for keeping good potency.

Out of the 41 new derivatives, compounds $17 \mathrm{~b}, 24 \mathrm{~d}$, and $28 \mathrm{e}$ demonstrated the promising anti-CVB3 effects with SI over 92.4, and then all of them were chosen for next investigation. Their antienteroviral activities against another four coxsackievirus B subtypes, including CVB1, CVB2, CVB5, and CVB6, were carried out using $\mathrm{RBV}$ as the positive control. As described in Table 3, compounds $\mathbf{1 7 b}$ and $\mathbf{2 4 d}$ afforded potencies against the four tested $\mathrm{CVBs}$ with $\mathrm{IC}_{50}$ ranging from 0.62 to $12.6 \mu \mathrm{M}$ (SI from 39 and 275), indicating broadspectrum antienteroviral activities against different types of CVB. It was noteworthy that compound $24 d$ exhibited a promising broad-spectrum antienteroviral effect against five coxsakievirus B subtypes with average $\mathrm{IC}_{50}$ of $1.4 \mu \mathrm{M}$ (average SI = 142), much better than that of RBV with average SI of 6.7, and was thus selected for further investigation.

Taken together, 41 new $N$-benzenesulfonyl sophocarpinic acid/ester and sophocarpinol derivatives were designed, synthesized, and evaluated for their antienterovirus activities against CVB3. SAR analysis revealed that (i) the double-bond and its configuration and position at the 11-attachment could

Table 3. Antienteroviral Activities against Four CVB Subtypes of Representative Compounds

\begin{tabular}{|c|c|c|c|c|c|c|c|c|c|c|c|c|}
\hline \multirow[b]{2}{*}{ compd } & \multicolumn{3}{|c|}{$17 b$} & \multicolumn{3}{|c|}{ 24d } & \multicolumn{3}{|c|}{$28 \mathrm{e}$} & \multicolumn{3}{|c|}{$\mathrm{RBV}$} \\
\hline & $\mathrm{TC}_{50}(\mu \mathrm{M})^{a}$ & $\mathrm{IC}_{50}(\mu \mathrm{M})^{b}$ & $\mathrm{SI}^{c}$ & $\mathrm{TC}_{50}(\mu \mathrm{M})^{a}$ & $\mathrm{IC}_{50}(\mu \mathrm{M})^{b}$ & $\mathrm{SI}^{c}$ & $\mathrm{TC}_{50}(\mu \mathrm{M})^{a}$ & $\mathrm{IC}_{50}(\mu \mathrm{M})^{b}$ & $\mathrm{SI}^{c}$ & $\mathrm{TC}_{50}(\mu \mathrm{M})^{a}$ & $\mathrm{IC}_{50}(\mu \mathrm{M})^{b}$ & $\mathrm{SI}^{c}$ \\
\hline CVB1 & 489.8 & 2.60 & 188.4 & 169.8 & 1.46 & 116.0 & 183.3 & 1.28 & 143.5 & 8196 & 1951 & 4.2 \\
\hline CVB2 & 489.8 & 12.6 & 38.9 & 169.8 & 1.44 & 117.2 & 127.1 & 7.61 & 16.7 & 8196 & 2101 & 3.9 \\
\hline CVB5 & 489.8 & 10.5 & 46.7 & 169.8 & 3.63 & 46.8 & 73.4 & & & 8196 & 910.8 & 9.0 \\
\hline CVB6 & 489.8 & 2.81 & 174.3 & 169.8 & 0.62 & 275.5 & 61.1 & 0.44 & 139.4 & 8196 & 1708 & 4.8 \\
\hline
\end{tabular}

${ }^{a}$ Cytotoxic concentration required to inhibit Vero cell growth by $50 \%$. ${ }^{b}$ Concentration required to inhibit CVB growth by $50 \%$. ${ }^{c}$ Selectivity index: $\mathrm{TC}_{50} / \mathrm{IC}_{50}$. 
not greatly affect the potency; (ii) the replacement of carboxyl with ester or alcohol might significantly improve the activity against CVB3. Among them, sophocarpinol 24d exhibited the highest potency against CVB3 as well as CVB1, CVB2, CVB5, and CVB6, indicating a broad-spectrum antienteroviral feature. The SAR results provided the powerful information on further strategic modification and optimization. Overall, $N$-benzenesulfonyl matrinic acid derivatives, as a new series of compounds, offer an attractive and promising starting point for further optimization and development of a novel scaffold of broadspectrum antiviral agents against enteroviruses.

\section{ASSOCIATED CONTENT}

\section{S Supporting Information}

Synthetic procedure, analytical data, antiviral assays, and cytotoxicity assay. This material is available free of charge via the Internet at http://pubs.acs.org.

\section{AUTHOR INFORMATION}

\section{Corresponding Authors}

*(D.S.) Tel: +86 10 63165268. Fax: +86 10 63165268. E-mail: songdanqingsdq@hotmail.com.

*(Y.L.) Tel: +86 10 63010984. Fax: +86 10 63010984. E-mail: yuhuanlibj@126.com.

\section{Author Contributions}

${ }^{\S}$ S.T. and L.K contributed equally to this work.

\section{Funding}

This work was supported by the National Natural Science Foundation of China (81321004 and 81402799), the Beijing Natural Science Foundation (7142107), and 863 Youth Project (SS2015AA020910).

\section{Notes}

The authors declare no competing financial interest.

\section{ABBREVIATIONS}

CVB, coxsackievirus B; SAR, structure-activity relationship; THF, tetrahydrofuran; TLC, thin layer chromatography; TBS, tert-butyldimethylsilyl; $\mathrm{Boc}_{2} \mathrm{O}$, di-tert-butyl pyrocarbonate; TEA, triethylamine; RBV, ribavirin; SI, selective index; Vero cells, African green monkey kidney cells; CPE, viral cytopathogenic effect

\section{REFERENCES}

(1) Derbyshire, J. B.; Jessett, D. M. Receptor activity for porcine enteroviruses in pig tissues. J. Med. Microbiol. 1969, 2, 489-493.

(2) Grist, N. R.; Bell, E. J.; Assaad, F. Enteroviruses in human disease. Prog. Med. Virol. 1978, 24, 114-157.

(3) Chawareewong, S.; Kiangsiri, S.; Lokaphadhana, K.; Wasi, C.; Pacharee, P.; Chavanich, L.; Thongcharoen, P. Neonatal herpangina caused by Coxsackie A-5 virus. J. Pediatr. 1978, 93, 492-494.

(4) Downing, C.; Ramirez-Fort, M. K.; Doan, H. Q.; Benoist, F.; Oberste, M. S.; Khan, F.; Tyring, S. K. Coxsackievirus A6 associated hand, foot and mouth disease in adults: clinical presentation and review of the literature. J. Clin. Virol. 2014, 60, 381-386.

(5) Yang, L.; He, D.; Tang, M.; Li, Z.; Liu, C.; Xu, L.; Chen, Y.; Du, H.; Zhao, Q.; Zhang, J.; Cheng, T.; Xia, N. Development of an enzyme-linked immunosorbent spot assay to measure serumneutralizing antibodies against coxsackievirus B3. Clin. Vaccine Immunol. 2014, 21, 312-320.

(6) Zhang, Y.; Zhu, H.; Ye, G.; Huang, C.; Yang, Y.; Chen, R.; Yu, Y.; Cui, X. Antiviral effects of sophoridine against coxsackievirus B3 and its pharmacokinetics in rats. Life Sci. 2006, 78, 1998-2005.

(7) Huber, S.; Ramsingh, A. I. Coxsackievirus-induced pancreatitis. Viral Immunol. 2004, 17, 358-369.
(8) Feuer, R.; Ruller, C. M.; An, N.; Tabor-Godwin, J. M.; Rhoades, R. E.; Maciejewski, S.; Pagarigan, R. R.; Cornell, C. T.; Crocker, S. J.; Kiosses, W. B.; Pham-Mitchell, N.; Campbell, I. L.; Whitton, J. L. Viral persistence and chronic immunopathology in the adult central nervous system following Coxsackievirus infection during the neonatal period. J. Virol. 2009, 83, 9356-9369.

(9) Midgley, C. M.; Jackson, M. A.; Selvarangan, R.; Turabelidze, G.; Obringer, E.; Johnson, D.; Giles, B. L.; Patel, A.; Echols, F.; Oberste, M. S.; Nix, W. A.; Watson, J. T.; Gerber, S. I. Severe respiratory illness associated with enterovirus d68-missouri and illinois, 2014. Morb. Mortal. Wkly. Rep. 2014, 63, 798-799.

(10) Biswas, T. Enterovirus 71 causes hand, foot and mouth disease outbreak in Cambodia. Natl. Med. J. India 2012, 25, 316.

(11) Osterback, R.; Vuorinen, T.; Linna, M.; Susi, P.; Hyypia, T.; Waris, M. Coxsackievirus A6 and hand, foot, and mouth disease, Finland. Emerg. Infect. Dis. 2009, 15, 1485-1488.

(12) Ge, M.; Wang, H. Q.; Zhang, G. J.; Yu, S. S.; Li, Y. H. The antiviral effec to fjiadifenoic acids $C$ against coxsackievirusB3. Acta Pharm. Sin. B 2014, 4, 277-283.

(13) Chen, S.; Chen, M.; Qian, F.; Xie, L. A clinical research of sophocarpine in treatment of viral myocarditis. J. Clin. Cardiol. 2005, $21,608-610$.

(14) Guo, B.; Li, C.; Deng, Z.; Chen, S.; Ji, Z.; Zhang, J.; Chen, M.; $\mathrm{Xu}$, F. A new method for measurement of (-)-sophocarpine, a candidate therapeutic for viral myocarditis, in plasma: application to a toxicokinetic study in beagle dogs. Rapid Commun. Mass. Spectrom. 2005, 19, 2840-2848.

(15) Gao, L. M.; Tang, S.; Wang, Y. X.; Gao, R. M.; Zhang, X.; Peng Z. G.; Li, J. R.; Jiang, J. D.; Li, Y. H.; Song, D. Q. Synthesis and biological evaluation of $\mathrm{N}$-substituted sophocarpinic acid derivatives as coxsackievirus B3 inhibitors. ChemMedChem 2013, 8, 1545-1553.

(16) Du, N. N.; Li, X.; Wang, Y. P.; Liu, F.; Liu, Y. X.; Li, C. X.; Peng, Z. G.; Gao, L. M.; Jiang, J. D.; Song, D. Q. Synthesis, structure-activity relationship and biological evaluation of novel $\mathrm{N}$-substituted matrinic acid derivatives as host heat-stress cognate 70 (Hsc70) downregulators. Bioorg. Med. Chem. Lett. 2011, 21, 4732-4735.

(17) Du, N. N.; Peng, Z. G.; Bi, C. W.; Tang, S.; Li, Y. H.; Li, J. R.; Zhu, Y. P.; Zhang, J. P.; Wang, Y. X.; Jiang, J. D.; Song, D. Q. Nsubstituted benzyl matrinic acid derivatives inhibit hepatitis $C$ virus (HCV) replication through down-regulating host heat-stress cognate 70 (Hsc70) expression. PLoS One 2013, 8, e58675.

(18) Cotarelo, M.; Catalan, P.; Sanchez-Carrillo, C.; Menasalvas, A.; Cercenado, E.; Tenorio, A.; Bouza, E. Cytopathic effect inhibition assay for determining the in-vitro susceptibility of herpes simplex virus to antiviral agents. J. Antimicrob. Chemother. 1999, 44, 705-708. 